\title{
Balaton, a pszichés teljesítmény mérésére alkalmas készülék trosz
}

\section{A MŰ́SZER LÉTREJÖTTÉNEK KÖRÜLMÉNYEI}

Az űrkutatók a hidegháború éveiben - nyugaton és keleten is - „szigorúan titkos” és „titkos” minősítésű témákon dolgoztak. A civil világ a katonailag minősített tudományos kutatásoknak csak melléktermékeivel ismerkedhetett meg. A versengés nemcsak az ürfegyverek kifejlesztése terén zajlott, hanem az ürrepülések kedvezőtlen élettani hatásainak megismerése terén is. 1966-ban a szocialista országok (hasonlóan a NATO országokhoz) a világűr kutasára vonatkozó szabályzatot fogadtak el, és részletesen kidolgozták az ürkutatás titkosságának megőrzésére irányuló szigorú előirásaikat, amelyek az űrélettani kutatásokra is kiterjedtek. A kutatásokról csak a hivatalos névjegyzékben szereplő közvetlenül érdekeltek tudhattak, akik a dokumentációikat a titkos ügyviteli szabályzat szerint voltak kötelesek kezelni. Egyes űrélettani kutatási eredményeket nem volt szabad publikálni, azokról csak zártkörű konferenciákon és munkaértekezleteken számolhattak be. A tudományos kutatómunkával kapcsolatos információcsere nyugaton az USAF, a NATO és a NASA, keleten pedig a Varsói Szerződés, valamint az Interkozmosz repülő- és ürorvosi, illetve űrélettani szimpóziumain és munkaértekezletein, zárt körben zajlott. Időnként a nyugat és a kelet szakemberei jól kontrollált viszonyok között találkozhattak egymással az IAF és a IUPS fórumain. A titkosszolgálatok ügyeltek arra, hogy ilyenkor csak célzott információ-cserére kerülhessen sor. Magyarországon jól szervezett cenzori szolgálat működött az űrélettani kutatások publikálása területén. Ennek megfelelően az információ-feldolgozó képességre (IFK) vonatkozó kutatások is csak részlegesen kerülhettek nyilvánosságra.

A hidegháború éveiben a repülés és az űrrepülés rohamos fejlődése következtében az ember-gép rendszer gyenge pontjává a pilóta vált. A katonai repülés és a katonai ürrepülés egyes szakaszain a testi és lelki terhelés meghaladta az emberi teljesítő képesség határait. Az alábbiakban példaként ismertetendő katasztrófa-statisztikák és rendkívüli események rámutatnak a hidegháború éveiben kialakult helyzet súlyosságára.

\section{1. ábra. A Tisza árterére, az elöntött szolnoki Szandai rétre zuhant MiG-15-ös}

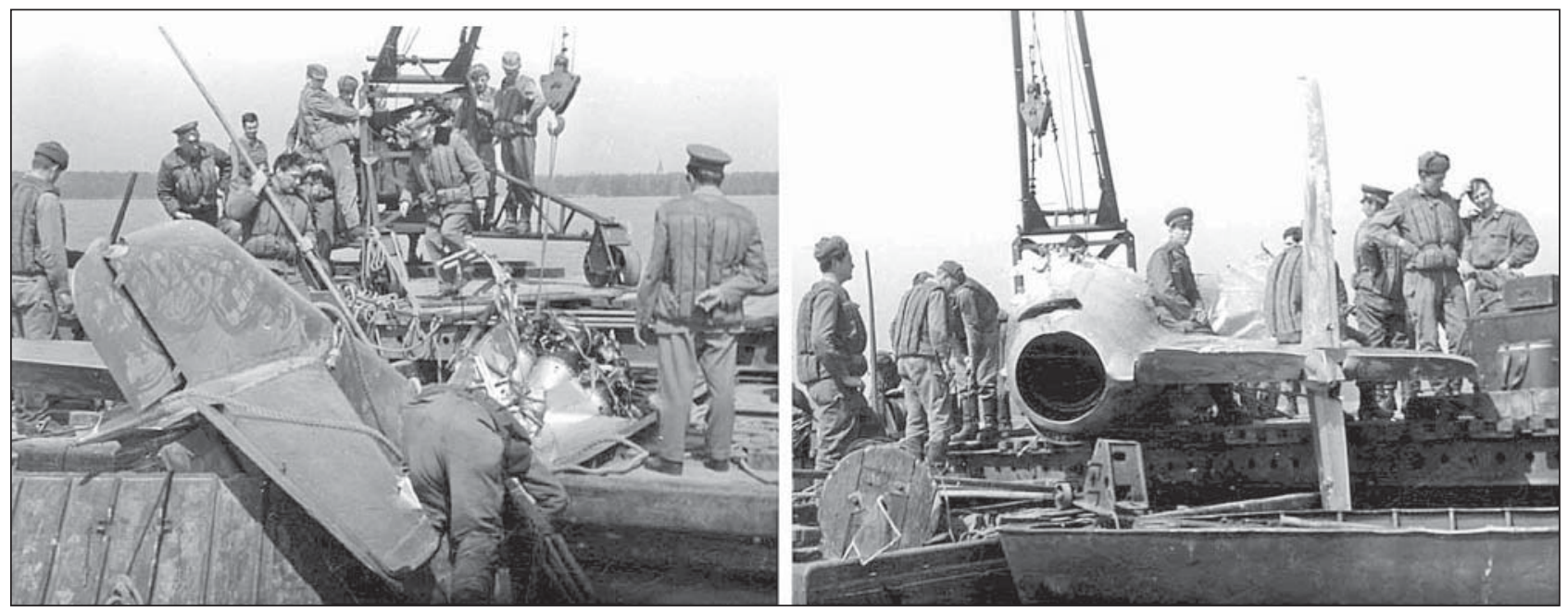

ÖSSZEFOGLALÁS: A magyar ürkutatók által kifejlesztett, a szellemi munkavégző képesség mérésére szolgáló módszer és müszer sikerrel működött a Szaljut-6 és Szaljut-7 fedélzetén. Segítségével a magyar kutatóknak a világon először sikerült lemérni az ürállomások fedélzetén, hogy az ürhajósok információ-feldolgozó képessége a súlytalanságban csökken.

KULCSSZAVAK: Szellemi munkavégző képesség, információ-feldolgozó képesség (IFK), bitsebesség, ưrélettudományok, pszichés teljesítmény
ABSTRACT: The method and istrument for measuring psychic performance, developed by Hungarian space researcers, had been used successfully on the board of Salyut- 6 and Salyut-7. With the help of this instrument, fot the first time in the world, Hungarian researchers had become able to measure the decrease of astronauts' information processing abilty on the space station board in weightlessness.

KEY WORDS: psychic performance, Information Processing Ability (IPA), bitspeed, Space Life Sciences, psychic power

Dr. Remes Péter ny. orvos ezredes, c. egyetemi docens, Szegedi Tudományegyetem Általános Orvostudományi Kar Repülő- és Űrorvosi Tanszék. www.drremes.hu. ORCID: 0000-0003-1715-1705. University of Szeged Faculty of General Medicine Department of Aviation and Space Medicine 


\section{A KATONAI REPÜLÉS KATASZTRÓFÁI MEGOLDÁST SÜRGETTEK}

A Magyar Néphadsereg hadrendjében álló (MiG-15, -17, -19 és -21 típusú) repülőgépei közül összesen $114 \mathrm{db}$ semmisült meg az 1951-1996 közötti években és ezzel kapcsolatban 74 magyar hajózó halt repülőhalált, míg 56 pilóta sikeresen katapultált. A NATO még rosszabb statisztikával rendelkezett.

A kedvezőtlen baleseti statisztika miatt joggal merült fel a kérdés, hogy miért ilyen gyakoriak a katasztrófák? A gépek irányítása meghaladja-e a hajózók információ feldolgozó képességeinek határait?

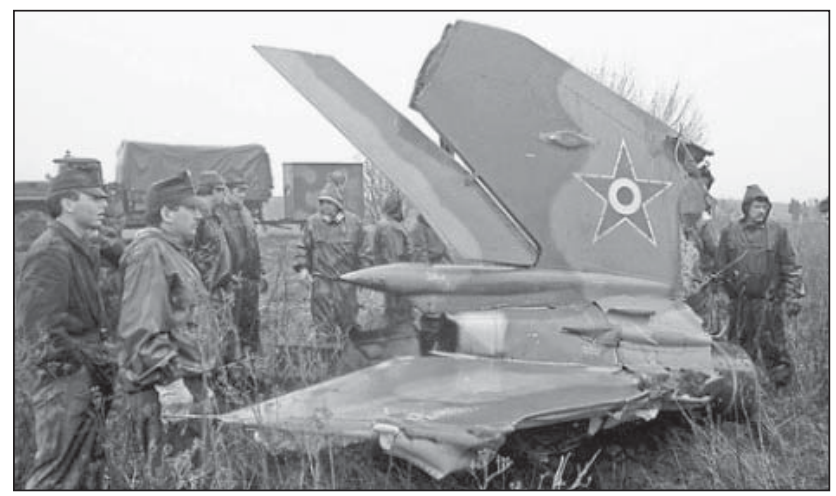

2. ábra. Az 1989. március 14-én lezuhant MiG-21-es
A KATONAI ÜRREPÜLÉS RENDKÍVÜLI ESEMÉNYEI FELHIVTÁKK A FIGYELMET A SZEMÉLYI TÉNYEZŐ SZEREPÉRE

Az 1960-as és 1970-es években a sorozatos rendkívüli események között még parancsmegtagadás is előfordult. A katonai ürrepülések történetében először W. Schirra szegült szembe a földi irányítással. 1968-ban, az Apolló-7 parancsnokaként a földi irányítás legnagyobb megrökönyödésére nyíltan és határozottan „függetlenítette” magát. Amikor a földi irányítás egy feladatot akart vele elvégeztetni, kifejtette, hogy „utálja” ezeket a dolgokat és „szemeteknek" titulálta a földieket. Komoly riadalmat keltett, amikor kijelentette, hogy "elegem van, mostantól fogva én leszek a repülés-irányító, nem megyek bele semmi új játékba”. Önkényesen megváltoztatta a gyógyszerelési utasításokat is, és nem volt hajlandó a sisakban való leszállásra sem, ahogy azt a szabályzat előírta volna. Belegondolni is rossz, ha ezt az ellenszegülést egy atombombával megrakott űrhajó parancsnokaként követte volna el.

Itt is felmerült a kérdés, hogyan juthat el egy jól felkészített pilóta a parancsmegtagadásig? Milyen törvényszerüségek szabályozzák az operátori tevékenység megbízhatóságát?

Egy másik esetben, 1976-ban a katonai rendeltetésű Szaljut-5 űrállomás (valójában egy Almaz osztályú űrbe telepített harcálláspont) fedélzetén B. Volinov űrhajóparancsnok és V. Zsolobov fedélzeti mérnök teljesített szolgálatot, amikor váratlanul lekapcsolódott a világítás, majd

1. táblázat. A magyar vadászrepülőgép-veszteségek gyakorisága

\begin{tabular}{|l|l|c|c|c|}
\hline \multicolumn{1}{|c|}{ Évszám } & \multicolumn{1}{|c|}{ Géptípus } & $\begin{array}{c}\text { Megsemmisült } \\
\text { gépek száma }\end{array}$ & $\begin{array}{c}\text { Repülöhalált halt } \\
\text { hajózók száma }\end{array}$ & $\begin{array}{c}\text { Sikeresen katapultált } \\
\text { hajózók száma }\end{array}$ \\
\hline 1951-1968 & MiG-15 & 35 & 39 & 4 \\
\hline 1955-től & MiG-17 PF & 1 & 1 & - \\
\hline 1955-től & MiG-17 F & 1 & - & 1 \\
\hline 1960-1973 & MiG-19 PM & 3 & 2 & 15 \\
\hline 1973-1996 & MiG-21 F-13 & 29 & 14 & 5 \\
\hline & MiG-21 PF & 7 & 2 & 6 \\
\hline & MiG-21 MF & 9 & - & 7 \\
\hline & MiG-21 bisz-75A & 7 & 3 & 10 \\
\hline & MiG-21 bisz-75AP & 13 & 10 & 8 \\
\hline & MiG-21 U, és UM & 9 & $\mathbf{3 2}$ & $\mathbf{5 1}$ \\
\hline & MiG-21 összesen & $\mathbf{7 4 ~} \mathbf{d b}(\mathbf{2 5} \%)$ & & \\
\hline
\end{tabular}

2. táblázat. Három NATO-ország veszteségeinek gyakorisága

\begin{tabular}{|c|c|c|c|}
\hline Évszám & Géptípus & $\begin{array}{l}\text { Rendszeresített } \\
\text { gépek száma }\end{array}$ & Veszteség \\
\hline Luftwaffe 1960-tól & $\begin{array}{l}\text { F-104 F, F-104 G, TF-104 G és } \\
\text { F/RF-104 G Starfighter "özvegycsináló” }\end{array}$ & $915 \mathrm{db}$ & $\begin{array}{l}30 \% \\
270 \text { gép összesen } \\
2 \text { gép/havonta } \\
139 \text { gép/100 } 000 \text { repült óra }\end{array}$ \\
\hline Kanadai légierő & CF-104 & $200 \mathrm{db}$ & $\begin{array}{l}25 \% \\
50 \mathrm{db}\end{array}$ \\
\hline Norvég légierő & CF-104 & n.a. & $\begin{array}{l}6 \text { gép/56 } 000 \text { repült óra } \\
10 \text { gép/100 } 000 \text { repült óra }\end{array}$ \\
\hline
\end{tabular}




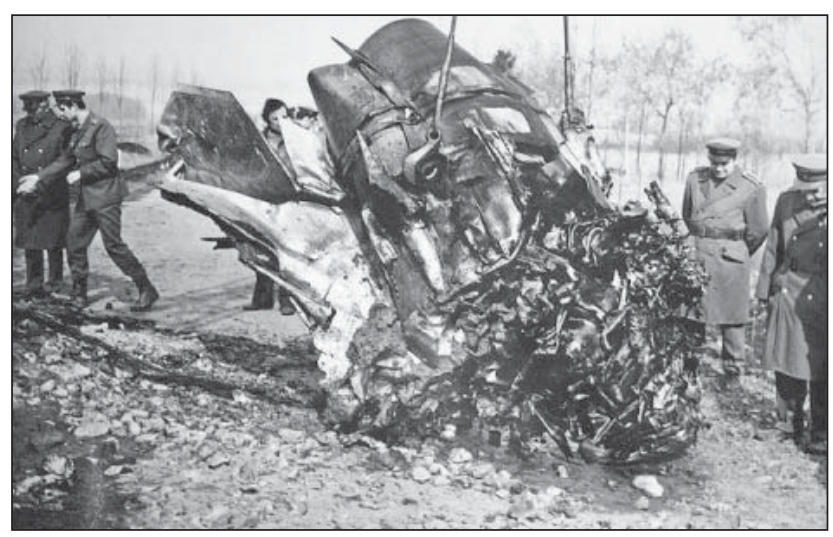

3. ábra. 1975. május 15-én egy MiG-21F-13 típusú gép katasztrófája

leálltak a fedélzeti rendszerek is, és az űrhajósok életveszélybe kerültek.

Nagy nehézségek árán, lépésről lépésre sikerült visszaálítaniuk a rendszereket és két óra múlva az űrállomás életre kelt.

V. Zsolobov fedélzeti mérnöknél a stressz nem múlt el nyomtalanul. „A stressz következtében Vitalíjnál (V. Zsolobovnál) semmilyen gyógyszerre nem szűnő, befolyásolhatatlan, erős fejfájás kezdődött. Megtagadta a futószőnyegedzéseket, inkább csak relaxált állapotban úszkált a fedélzeten. Kettőnk helyett kellett dolgoznom" - emlékezett társa. A gyors állapotromlás miatt, a 60 naposra tervezett ürutazást a 42. napon meg kellett szakítani. Ekkor már V. Zsolobov olyan rossz állapotban volt, hogy a szkafanderét sem tudta felvenni. $B$. Volinov öltöztette fel, és kötözte be az ülésbe a mély stuporozus állapotban lévő űrhajóst.

B. Volinov ürhajóparancsnok kénytelen volt egyedül, a fedélzeti mérnök segítsége nélkül hozzálátni a leszálláshoz. A földet érés nem sikerült. Az ejtőernyőn lóbálózó űrhajó éppen a legnagyobb kilengésében volt, amikor a puha leszállást biztosító földközeli fékező rakéták működésbe léptek, ezért azok az űrhajót nem fékezték le, hanem odébb

\section{4. ábra. B. Volinov a Szaljut-5} parancsnoka

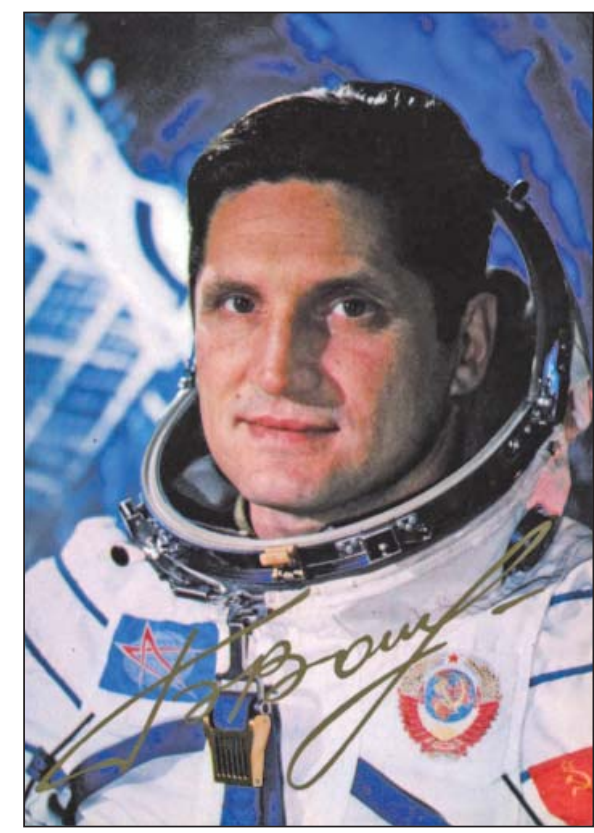

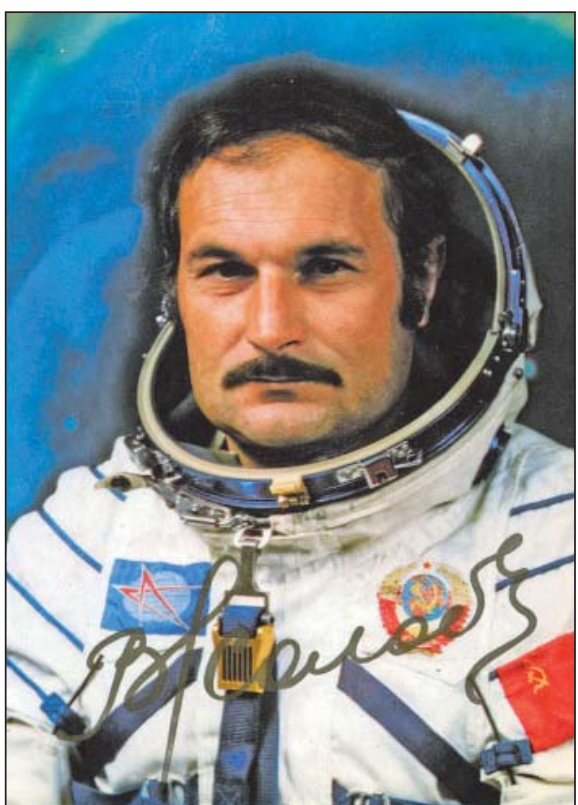

5. ábra. V. Zsolobov a Szaljut-5 fedélzeti mérnöke

lódították. Az űrhajó az élével csapódott a fölhöz, majd 8 méterre visszapattant, és az oldalán csúszva ált meg. A kemény földet érés miatt $V$. Zsolobov szkafandersisakja beszorult, és a feje is megsérült. Az első kiszabadítási kísérletet az elektromos vezetékek rövidzárlata és szikrázása miatt félbe kellett szakítani. Csak a második kísérletre sikerült V. Zsolobovot kihúzni az ülésből. Az ürhajósoknak jártányi erejük sem volt, szinte magatehetetlenül feküdtek a leszállóegység mellett a füben. „Eljött az idő, amikor úgy éreztem, hogy mi már nem élünk, erre nagyon jól emlékszem, ez nem félelem volt, hanem egy abszolút közömbösség, csak arra gondoltam, hogyan hagyhattam ott az enyéimet a földön?" - mondta később V. Zsolobov.

Ez az eset az ürrepülés megoldatlan pszichológiai problémáira hívta fel a figyelmet. Újra és újra felmerült a kérdés, hogy milyen hatásai vannak az űrrepülés stressz tényezőinek az ürhajósok szellemi munkavégző képességére, hogyan lehet lemérni az emocionális feszültség szintjét, hogyan alakult ki a hajózók rezerv nélküli állapota? Biofeedback technika segítségével befolyásolni lehet-e az emocionális feszültség szintjét, illetve az információ-feldolgozó képesség, az emocionális feszültségszint és a rezerv nélküli állapot mérésével távol lehet-e tartani a repüléstől az alkalmatlan jelölteket?

6. ábra. A biofeedback technika segítségével befolyásolni lehet az emocionális feszültség szintjét

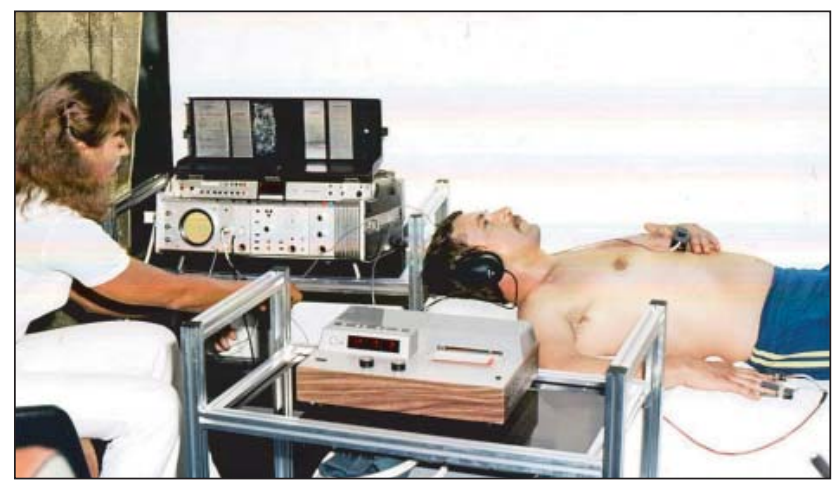




\section{ÜRÉLETTUdománYI KUTATÁSOK a VARSóI SZERZődÉS TAGÁLLAMAIBAN}

A rendkívüli események és katasztrófák magas száma megoldást sürgetett. Ezekben az években a Varsói Szerződés (VSz) Politikai Tanácsadó Testülete felügyelte a tagállamok valamennyi politikai, gazdasági és kulturális szervét, Katonai Tanácsa és a Honvédelmi Miniszterek Bizottsága pedig a szerződő feleknek beleszólási jogot biztosított a katonapolitikai kérdésekbe. A VSz Egyesített Fegyveres Erőinek Főparancsnoksága a tagállamok Vezérkari Főnöksége alárendeltségében lévő egészségügyi szolgálatfőnökein keresztül felügyelte az orvos-biológiai kutatásokat. Az egészségügyi szolgálatfőnökök rendszeresen találkoztak az úgynevezett koordinációs értekezleteken, ahol meghallgatták a beszámolókat, megvitatták az elért kutatási eredményeket és elfogadták a következő öt évre szóló munkaterveket. Tíz szekcióban folytak a tanácskozások, az űrélettudományi kutatásokkal a IX. repülőorvosi szekció foglalkozott. A honvédorvosok ennek megfelelően nemzetközi kooperációban végezték ürélettudományi kutatásaikat. A VSz titkos probléma-katalógusában a Покой (Pokoj: nyugalom) fedőnevű fejezet „A hajózó tevékenység pszichofiziológiai és higiénés sajátosságainak tanulmányozása, a repülés előtti és alatti munkaképesség dinamikus megfigyelésére alkalmas orvosi kontroll effektusának növelése céljából" című 4. témán belül, a magyar fél elvégezte a pilóták szellemi munkavégző képességének vizsgálatát. Megvizsgálta reális repülések előtt és után a hajózó állomány munkavégző képességét. IFK méréseket és longitudinális EKG-vizsgálatokat végzett reális repülések alatt, felmérte a hajózók emocionális feszültségszintjét és pszichés rezerveiket.

Az Аккредитив (Akregyitív: hitellevél) fedőnevű fejezet „A katonai szakemberek pszichofiziológiai kiválogatása” című 6 . témán belül a magyar fél a prognosztikai modell kifejlesztésével és kipróbálásával foglalkozott.

A 7. téma koordinálását a Magyar Népköztársaság végezte, részt vettek benne a bolgár, német, lengyel, szovjet, csehszlovák és román kutatók. A Medicorral együttműködésben létrehozták és kipróbálták a KTD-1, KTD-8, KTD11 készülékcsaládot, kidolgozták a készülék műszaki-harcászati követelményeit, és rendszerbe állították a VSztagállamok hadseregei számára. Kidolgozták a BalatonPsychocalculator készülékcsaládot.

A kutatások eredményeiről a VSz szimpóziumain és munkaértekezletein az Interkozmosz Kozmikus Orvos-biológiai Állandó Munkacsoportjának ülésein, valamint a rájuk vonatkozó mértékben a MN honvédorvosai részére tartott továbbképzéseken számoltak be. Jelentéseiket a VSz tagállamoknak rendszeresen megküldték, illetőleg viszonossági alapon tőlük is rendszeresen megkapták.

\section{AZ INFORMÁCIÓ-FELDOLGOZÁs MÉRÉSÉNEK ELMÉLETI KIDOLGOZÁSA}

A kérdés tanulmányozására szolgáló magyar repülő- és űrorvosi kutatások 1972-ben kezdődtek. Információelméleti megfontolások alapján a pilóta-repülőgép rendszer működése a rendszerbe jutó, meghatározott tartalommal rendelkező információ-áramlással jellemezhető. A szignálok adása és válaszreakciók lemérése alapján meghatározható a rendszerben folyó információ-feldolgozás terjedelme, sebessége és áteresztőképessége. Shannon összefüggése alapján kiszámítható, hogy négyválasztásos fényszignál rendszer alkalmazása esetén, minden (egyenlő valószínűséggel, de véletlenszerű sorrendben adagolt) fény- felvillanással 2 bit információ feldolgozására késztethető a vizsgálati személy.

$$
I=-\sum \mathrm{Pi} \log _{2} P i
$$

ahol $I=$ a feldolgozott információ mennyisége, $P i=a z$ egyes szignál megjelenésének valószínűsége, amely az általa használt négyválasztásos rendszerben 0,25 értéket vesz fel.

$$
I=\sum\left(0,25 \log _{2} 0,25\right)=4\left(0,25 \log _{2} 0,25\right)=2 \text { bit. }
$$

Egy optimalizált mérési ciklus alatt 16 esetben vizsgálandó meg a kapott 2 bit információ-mennyiség feldolgozása, fel nem dolgozása, vagy hibás feldolgozása. 16 hibátlan reakció esetén 16-szor 2 bit feldolgozása történik meg, tehát a feldolgozott információ-mennyiség átlaga is 2 bit lesz. Az így meghatározott 2 bit információ-mennyiség csak hibátlan reakció esetén érvényes. Reakció hiánya az adagolt 2 bit információ-mennyiség észlelésének, feldolgozásának, vagy a válaszadás zavarát jelzi. Ép szenzomotoros státusz esetén a 2 bit fel nem dolgozását jelenti. Hibás reakció az adagolt 2 bit információ-mennyiség rossz feldolgozását, vagy a rossz válaszadást jelenti. Az alábbi számítás alapján meghatározható, hogy hiba esetén mennyire csökken az átvitt információ mennyisége. A reakció hiánya, a hibás reakciók és azok elhelyezkedése, valamint a helyes reakciók, azok elhelyezkedése és ismétlődése Wentzell mátrix módszerével határozható meg.

$$
I=\sum P s \log _{2} P s+\sum P r \log _{2} P r-\sum P s r \log _{2} P s r \text { alapján, }
$$

ahol

$P s=a z s_{1} s_{2} s_{3} s_{4}$ szignálok megjelenésének valószínüsége, $P r=a z r_{1} r_{2} r_{3} r_{4}$ reakciók valószínűsége,

$P s r=a z s r_{1} s r_{2} s r_{3} s r_{4}$ szignál és reakciókapcsolatok realizált variánsainak valószínúsége.

Kiszámítható, hogy az első hibás reakció egyazon helyen 0,22 bit átvitelét jelenti, a második hibás reakció egyazon helyen 0,11 bit; a harmadik 0,08 bit; a negyedik 0,05 bit; az ötödik pedig 0,04 bit információ átvitelét jelenti. Lemérve a vizsgálati személy egyszerű szenzomotoros reakcióidejét, majd az összetett (négyválasztásos) reakcióidejét, a kettő különbségéből meghatározható a választási idő. A feldolgozott információ-mennyiség és a választási idő hányadosa a bitsebesség. $R$ bitsebesség tehát a lemért bitszám és a választási idő hányadosa.

\section{$R=/$ bit / választási idő $\mathrm{sec}=R \mathrm{bit} / \mathrm{sec}$.}

Az információ-feldolgozó képesség (IFK) az úgynevezett $C=$ bitkapacitással is jellemezhető.

$$
C=R \cdot 1 / \log _{2} N \text {, }
$$

ahol $N=$ a választható szignálok száma.

Hibátlan reakciók esetén, négyválasztásos rendszerben,

$$
C=(R \cdot 2) / 2 \text {, vagyis } C=R \text {, }
$$

tehát a bitkapacitás egyenlő a bitsebességgel. Hibázás esetén, annak súlyossága szerint $C$ csökken.

Hick és Hyman törvényének megfelelően megállapítható, hogy az információ mennyisége és a reakcióidő között lineáris összefüggés áll fenn, mennél több a bitmennyiség, annál nagyobb a reakcióidő is. Az összefüggést koordináta rendszerben szemléltetve egy emelkedő görbe ábrázolódik. Gyakorlással a reakcióidő csökkenése érhető el, ilyenkor a görbe mindinkább a vízszinteshez közeledik. Az IFK a feladat bonyolultságától, valamint a szignál és a reakció lehető legjobb egybeesésétől is függ, ami rámutat a repülőgép műszerei (szignál) és vezérlőszervei (reakció) optimális kialakításának fontosságára. 


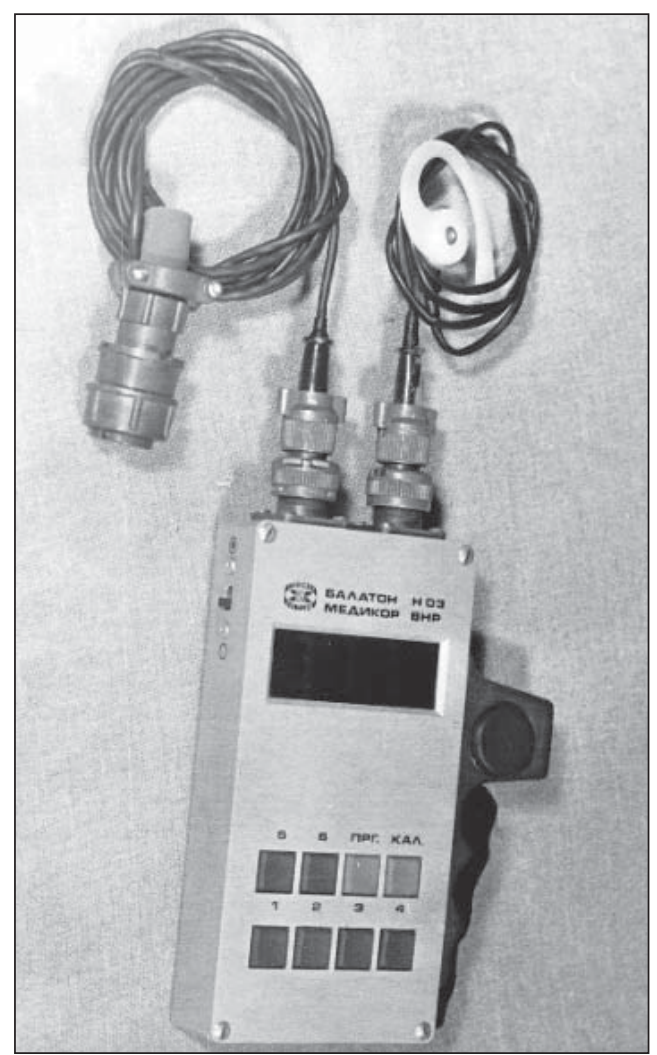

7. ábra. Az eredeti Balaton készülék a robusztus fedélzeti csatlakozókkal

\section{A BALATON KÉSZÜLÉK}

1975-ben a kecskeméti Repülőorvosi Vizsgáló és Kutatóintézet (ROVKI), illetve a Medicor Művek Kutató és Fejlesztő Intézete együttműködési szerződést kötött egy speciális repülőorvosi igények kielégítéséhez szükséges készülék fejlesztésével kapcsolatban. A ROVKI-ban hamarosan elvégezték a szükséges vizsgálatokat, illetve kidolgozták az IFK vizsgálatára alkalmas műszerrel kapcsolatos találmányi bejelentés elméleti alapjait és annak gyakorlati vonatkozásait. A készülék először Magyarországon, később az Egyesült Államokban is szabadalmi oltalmat kapott. A repülő- és űrorvosi specifikáció alapján a Medicor Művekben el is készült először Reflex néven az IFK mérésére szolgáló műszer, amely galvanikus bőrellenállás (GBR) meghatározására alkalmas mérőegységet is tartalmazott. Relax néven pedig a komplex táskadiagnosztikai készülékbe (KTD 11F) építették be. Az IFK mérőműszernek a Medicor 1976-ban a Balaton nevet adta.

Ez a műszer az akkori - nagy méretű, elektroncsöves és tranzisztoros - orvosi műszerek világában csúcstechnikának számító kis méretű, mikroprocesszoros készülék volt. A 420 gramm tömegű, könnyen kezelhető eszköz három részből állt, reakcióidő-mérőt, pulzusszámlálót és galvanikus bőrellenálás (GBR) -mérőt is tartalmazott. A programozható mikroprocesszor számos vizsgálati metodikát tartalmazott és képes volt a vizsgálati eredmények kiszámolására is. Akkoriban a programvezérelt orvosi vizsgálati metodika és a valós idejü (real time) adatfeldolgozás is orvostechnikai újdonságnak számított. Hanggenerátora egy fülhallgatóban hallható, véletlenszerűen előállított magas és mély hangokat tudott előállítani, ezáltal az IFK mérése közben hangzavarást is lehetett alkalmazni. A vizsgált személynek az IFK meghatározása közben össze kellett szá- molnia, hogy hány darab magas, illetőleg hány darab mély hangot hallott. llyen módon a figyelemmegosztás közben a rezerv nélküli állapottal arányos módon nőtt a hibázások száma, csökkent a bitsebesség, és a feldolgozott információ mennyisége. Az aktuálisan mért pulzusszámmal a fülhallgatóban hallható hangot modulálni is lehetett, így biofeedback és relaxációs vizsgálatok végzésére is alkalmas volt, illetőleg autogén tréningre is lehetett használni.

(Folytatjuk)

\section{ForRÁsOK}

Remes P. - Hideg J. - Bognár L.: Psychophysiologische methoden zur messung des dienst fahigkeit des flugzeugfuhrers. XX. VSZ Munkaülés. Drezda, 1985;

Remes P. - Pozsgai A. - Hideg J.- Lehoczky L. - Kiszely I.: 24 hours observation of pilots cardial satatus by Holter method. MN Repülőorvosi Vizsgáló és Kutató Intézet Tudományos Közleményei. Repülőorvosi Archívum Kecskemét, 1989;

Remes P. - Pozsgai A. - Hideg J. - Kiszely I. - Lehoczky $\mathrm{L}$.: Examination of the effect of G-load on cardiovascular system by Holter method. IUPS. Gravitational Physyology. Lyon, France. 1989. MN Repülőorvosi Vizsgáló és Kutató Intézet Tudományos Közleményei. Kecskemét, 1989;

Együttműködési szerződés egyrészről a Medicor Művek Kutató és Fejlesztő Intézet, másrészről a MN Repülőorvosi Vizsgáló és Kutató Intézet között. Repülőorvosi Archívum Kecskemét, RAK 197504 16.;

Remes P.: Jelentés és találmányi javaslat az információ feldolgozó képesség vizsgálatára alkalmas műszerrel kapcsolatban. Repülőorvosi Archívum Kecskemét, RAK 197504 16.;

Eljárás cortikális információ feldolgozási képesség meghatározására választásos reakcióméréssel és berendezés ennek foganatosítására. Országos Találmányi Hivatal. Szabadalmi okirat. Repülőorvosi Archívum Kecskemét, RAK 197809 15.;

Eljárás és berendezés az aktuális pszichofizikai állapot komplex vizsgálatára. Danubia Szabadalmi Iroda. Közzétételi példány. Repülőorvosi Archívum Kecskemét, RAK 198306 15;

Hideg J. - Bognár L. - Remes P. - Kozarenko O. Miasnikov V. I. - Ponomareva, I. P.:

Psychophysiological performance examination onboard the orbital complex Salyut-Soyuz. International Astronautical Congress. Paris. 1982. In L. G. Napolitano: Space 2000. Published by American Institute of Aeronautics and Astronautics New York. 1982;

Remes P. - Hideg J. - Bognár L. et al.: Changes in information processing ability (IPA), EEG, EOG using passive orthostatic and antiorthostatic test. Hungarian Academy of Sciences, Intercosmos Council, Budapest, Hungary. NASA. 84A24347\# Issue 9, Page 1293;

Remes P. - Hideg J. - Bognár L. - Lehoczki L.- Pozsgai A. - Sidó Z.: Untersuchungsmethoden zur Beurteilung der Leistungsfahigkeit des Menchen für die Zwecke der Luftfahrtmedizinischen Begutachtung. Zeitschrift für Militar Medizin. 24. Jahrgang, October, 1983. p. 236-237.

Grósz A.: A katonai repülő-hajózó állomány vizuális munkavégző képességének mérési tapasztalatai. Kandidátusi értekezés. Budapest. 1991. 